\title{
Embedding Social Innovation in Latin America Academic Curriculum
}

\author{
Galego, Diego $^{a}$; Soto, Waldo ${ }^{\mathrm{b}}$; Carrasco, Gabriela ${ }^{\mathrm{b}}$; Amorim, Marlene ${ }^{\mathrm{a}}$ and Ferreira \\ Dias, Marta ${ }^{a}$ \\ ${ }^{a}$ Department of Economics, Management, Industrial Engineering and Tourism and \\ GOVCOPP, Research Unit on Governance, Competitiveness and Public Policies, \\ University of Aveiro, Portugal, ${ }^{\mathrm{b}}$ Ashoka-U, Chile.
}

\begin{abstract}
Recently we have witnessed the growth of social innovation initiative as a viable approach to address many challenges of contemporary societies across the social, cultural, economic, educational and environmental domains. Social innovation sets up to develop alternative, and sustainable, solutions to social issues by means of organizational models that rely on strong civic engagement and participation across private and public sectors. As such, social innovation holds a strong potential for the transformation of societies and has attracted a growing interest from researchers, practitioners and policy makers around the world. A key domain of concern is the need for developing adequate models and methodologies for the qualification of individuals for social innovation. In this vein the Student4Change project aims to develop and implement an integrative methodology to embed social innovation and entrepreneurship in the academic experience of students in Latin America. This paper offers a preliminary description of the advancements led by 10 universities in 5 Latin America countries engaged in the project, in order to develop competences for social innovation and social entrepreneurship through innovations in academic curricula.
\end{abstract}

Keywords: Social Innovation; Social Entrepreneurship; Universities; Latin America; Students4Change. 


\section{Introduction}

At the heart of the social innovation and social entrepreneurship movement in Europe, many initiatives have been taking place, often as responses to pressures from youth unemployment numbers. The social enterprise movement, the typical vehicle to scaling up social innovation, emerges in this context as an organizational model that can support a diversity of initiatives to address social, cultural and environmental challenges (Bikse, Rivza, \& Riemere, 2015). Overall, the last decades, the European landscape, has been marked by a significant increase in the number of social enterprises as one of the ways to solve social issues (Bikse et al., 2015).

Individuals and organizations that are putting forward innovative organizational models to address societal challenges are the promoters of social entrepreneurship. Usually this class of entrepreneurs is highly motivated towards addressing community problems, and leads the identification of innovative answers (Zahra, Gedajlovic, Neubaum, \& Shulman, 2009). In order to sustain such solutions, they need to be willing to take risks and actively seek for the necessary resources, partners and stakeholders to implement their projects (Abu-Saifan, 2012). The Office for Social Innovation launched by White House in US, followed by UK, have started, since then known a generalized dissemination worldwide. While social innovation appears to be a sustainable solution for social problems, this notion has been criticized for the broad understanding about the concept being vague, and has gained attention in policy debates, governmental interests and project priorities (Fougère, Segercrantz, \& Seeck, 2017; Păunescu, 2014). Social innovation can build on very diversified activities, including the nonprofit economy, social entrepreneurship, social economy, services sector, and in corporate social responsibility practices (Martinez, Gonzalez Alvarez, \& Nieto, 2015; Mulgan, Tucker, Ali, \& Sanders, 2007). The diversity and proliferation of examples is calling for specific competences to enable their promoters to set up sustainable models that guarantee the continuous engagement of communities. Despite the dissemination of the social innovation movement, in Europe as well as in Latin America, its effective implementation and sustainability is largely deenent on the involvement and engagement with local communities. Academics, social innovators and policy makers, all need to understand more about such organizational and entrepreneurial process, in order to act towards its strengthening in their respective contexts (Herrera \& Ugarte, 2008).

According to Domanski, Howaldt, \& Schroder, (2017), social innovation in Latin America is creating approaches to face and minimize social problems within a modern economic development, taking into consideration the less incentives addressed by government into a sustainable welfare and quality of life. The economic crisis has caused that more innovative initiatives are emerging in many countries in Latin America (Herrera \& Ugarte, 2008). Universities can have an important role in the development of local "social innovation 
ecosystems", specially in the training and inspiration of students willing to be part of it (Cunha, Benneworth, \& Oliveira, 2015). Recent evidence suggests that Universities have been developing different programs and ways to introduce social innovation in their education mission, either as mandatory courses, or as extra-curricular programs, but strongly as a response to an emerging demand. However, we still lack a shared vision of social innovation as an academic field, much because of the existing different contexts for the understanding of social innovation, and consequently the existence of a fragmented view and discourse about it (Păunescu, 2014).

Students4Change, is an international project with capacity building purposes, that targets Latin American universities, with the objective of contributing to address the calls for education and training that stem from the practice, and the demands for social innovation. The aim of this project is to integrate social innovation in curricula and learning environments at the partner universities, improving the quality and relevance of its academic programs in relation to the skills that ought to be developed by students in order to solve the social problems affecting their regional context. The present study attempts to offer a broad view of the social innovation field, which can deliver to scholars and researchers a brief characterization of the reality in Latin America concerning on the implementation of social innovation and its potential feasibility under the Higher Education Institutions (HEIs) scope and influence in society in that region.

As the definition of social innovation is still a work in progress, lacking academic and international consensus, the project embraced a preliminary task of building a shared understanding about the concept, based on the existing literature as well as in insights provided by all partner universities. In order to define the main concepts a qualitative analysis of data was performed. The various definitions offered by the project partners evidenced some consistent elements. The ingredients identified in the social innovation definitions were also aligned with the framing of social innovation found in prevalent research and institutional documents relevant in the field.

\section{Data Collection, Results and Discussion}

This study offers an overview of two data collection efforts conducted across Latin America Higher Education Institutions. A first data collection exercise aimed at achievind a shared and meaningfull vision of social innovation and social entrepreneuship, to support the development of learning to integrate its awareness and promotion in academic curricula. To this end a questionnaire was developed and conducted with informants from the 10 project partners in Latin America, in five countries (Brazil, Chile, Colombia, Costa Rica 
and Mexico), for a sample of two universities by each country, in the context of the Project Students4Change ${ }^{1}$ (www.uestudents4change.org/).

The questionnaires were applied to professors, acquainted and involved with social innovation as well as to members of rectorate and other management representative, project managers and other institutional experts in social innovation. The respondents were asked to distinguish the concepts of social innovation and social entreprenseuship as well as to mention what were the prevalent sources in academic literature that were used to support and inform their action and thought in the context of their institution. This way the data collection aimed to capture an institutional shared view over social and entrepreneurship innovation. This data was subject to a qualitative analysis, that led to the identification of key elements in the institutional understanding concerning the concepts and references on this topic in Latin American universities.

The second data colletion effort concerned the identification of metodologies, teaching and learning practices that were currently being employed by the same sample of universities to the students, in order to develop competences for social innovation and entrepreneurship innovation. This data colletion aimed to target evidence about learning approaches, practices and tools as well as innovative curricula experiences, such as the development real projects with local communities in the curricula experience.

In what concerns the search for a common understanding of social innovation and social entreprenseuship, the data analysis allowed for the identification of three key common defining elements about Social Innovation: 1) the idea of social innovation as a new solution specifically developed to address a social need or challenge; 2) the distinguishing characteristic of an ample and diversified participation of social actors in the processes of social innovation; 3 ) the association of social innovation with social change and impact.

The definitions for social entrepreneurship offered by the partners of this project revealed an evident association of the ideas of social innovation, notably in what concerne the goals, the objectives, the purposes of ventures/organizations/entreprises created under such label. Also, the understanding of Social Entrepreneurship in the context of Students4Change can by summarized into: 1) A Purposeful Entrepreneurship, i.e. aiming at social good; 2) An organization based on Sustainable Resource Management Model.

Beyond the effort of putting together a common definition to work and the similarities that the exercise brought between the parteners, the general conclusion is that, there is a lack of a formal or unique definition and/or understanding in terms of social innovation and entrepreneurship. That is not only distinct in their declarations of meaning but also in the

\footnotetext{
${ }^{1}$ Erasmus+ Project number: 574133-EPP-1-2016-1-MX-EPPKA2-CBHE-JP
} 
approach each university takes and the practices they characterize as social innovation initiatives.

In what concerns the information gathering about the existing teaching and learning approaches and practices, a total of 48 courses with social innovation and social entrepreneuship ingredients were reported, spread across 42 undergraduate disciplines $(87 \%)$ and 6 postgraduate disciplines (13\%). Reports emerged from very diversified academic areas, notably such as, health, agriculture, economy, entrepreneurship, management, visual design, business, social responsibility, urban planning, rural development and software engineering, for undergraduate courses addressing social innovation methodologies. For postgraduate areas examples ranged from project and technological management, social economy, entrepreneurship, innovation and creativity challenges were described as more common lines of student preparation pointed by several universities. The diversity of areas of studies reported on this study can, to some extent, be explained by the existing ambiguity in the understanding of the concepts, something that can lead to an inadequate classification of the courses as social innovation or social entrepreneurship courses (to see Fig.1).

These results aim to offers a first building block to the understating of social innovation and social entrepreneurship, as well as to shed ligh on the eduction practices that can contribute to their development. To that end, as it undertakes an overview and an analysis of the existing courses reported by universities, that they consider are facing social challenges, not necessarily as social innovation per se. In the context of the project Students4Change is previewed theconduction of a "Pilot Program", which will be further developed in subsequent phases, and that will involve the adoption of active learning approaches to promote social innovation awareness and competences on 50 academic diverse areas of studies, in various partner universities. Overall, the results suggest that many HEIs have already drafted education answers to this end, by means of punctual activities and training, but there is a generalized feeling about the need of formalizing a program specially design to promote social innovation, and to qualify the university professors for that endeavor. 

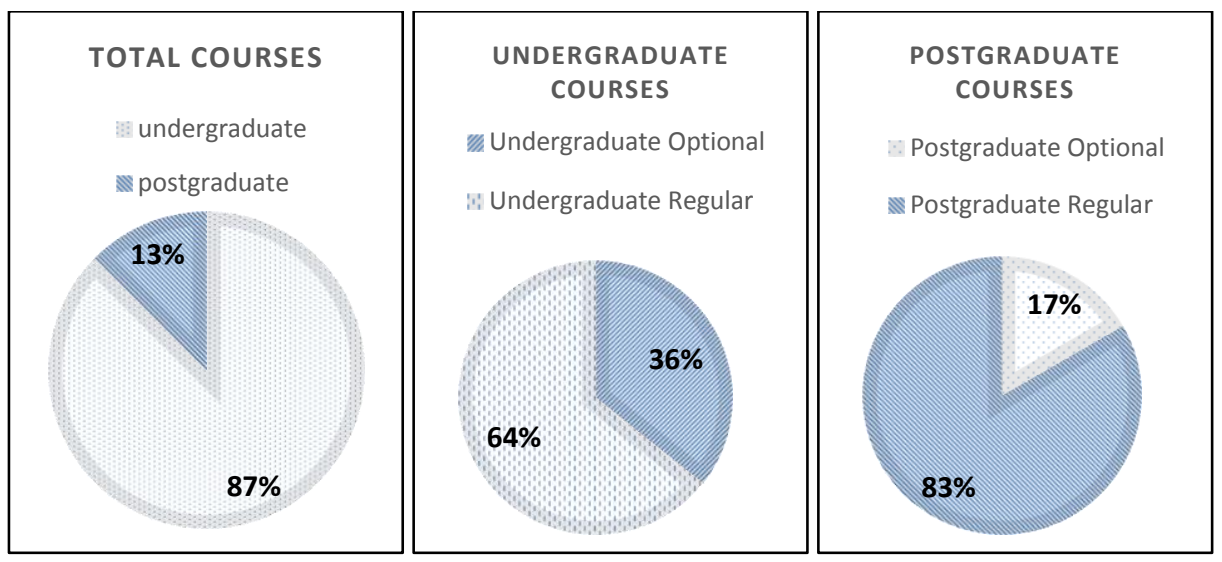

Figure 1. Distribution of the nature of the 48 courses reported by Latin America universities.

This insight about the social innovation and social entrepreneurship as a formal education, suggests what the universities are promoting in Latin America, and raises many research questions: How are universities embedding social innovation into their curricula courses? How they are addressing this change in academia? Which are the most common landscape of offers? The ongoing project attempts to answer such questions in further analysis addressed empirically, based on the evidence reported by partner universities showing a transversal understanding of theory and action, implicit in different initiatives underpinning the relationship between university and local community.

Another indicator seems to be relevant in this study is the methodologies reported by universities as transversal to conduct the social innovation and social entrepreneurship courses, representing the academic interventions and resources able to student in each institution. The Figure 2 presents the different formats where universities were pointing as much important on the institutional teaching and learning approaches.

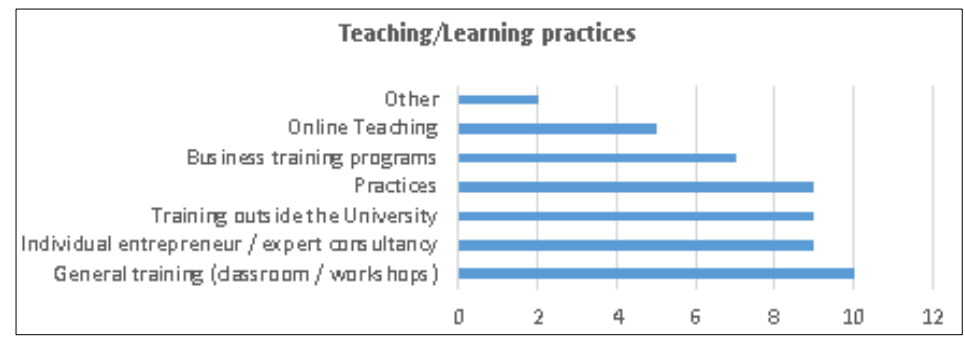

Figure 2. Reported teaching and learning approahces offered by the universities

Some fromats are well spread across the sample. General Training was pointed as a current methodology offered by all insititutions and Practices, Training outside the University and Individual entrepreneur/expert consultancy, were pointed as the second fundamental format for $93 \%$ (9) of the total respondent institutions (10). It shows that, the courses are engaged 
in their contextual society and improving the relationship extra instutional, bringing the "real cases" to inside the classroom scenario. On the contrary, Online teaching was less frequently reported as educational practices of teaching and research in the courses, being mentioned by only five universities.

Concerning the offered efforts of academic formation (see Figure 3), all the universities agreed that the most effective way of debates and dissemination of innovative strategies performed in academia is Conferences, which greatly enhance further intern and extern collaboration opportunities with peers. Subsequently followed by Series of Talk, Competitions and Practices, highlighting various types of formation, which can help to increase the options for students to have a more transversal academic degree.

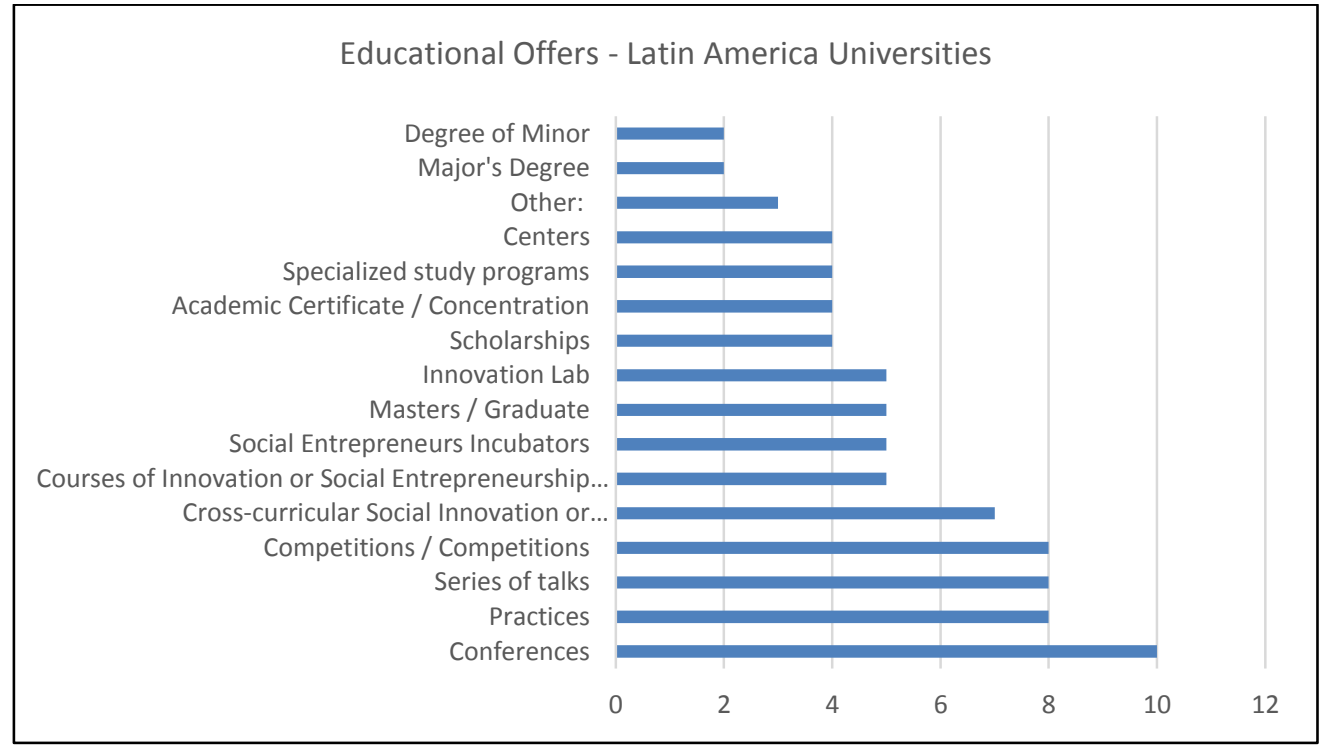

Figure 3. Social innovation and social entrepreneurship formation resources offered by universities

A relevant read can be found in results by contextual regions, where universities present a dynamic participation in their social community building bridges with external enterprises, underpinning the opportunity to link theory with practice. Transposing geographical barriers HEIs are leading to a new paradigm in social innovation and social entrepreneurship embedded in academic curricula, delivering goods and specialized services to the central or peripheral communities in urban and rural areas. More and more initiatives are awaking including the "social" term in entrepreneurial and innovative sectors, following supranational framework, attempting to fulfil the lack of resources and technical assistance. Indeed, this perception of the "academia relationship" towards a new paradigm to link university-industry-government, as known Triple Helix (Etzkowitz, 2008; Heitor, 2015) receive much more attention by emerging technological and polytechnic universities shifting the economic growth, social and cultural landscape in their host city. 
The social innovation and social entrepreneurship perspective will contribute to balance the HEIs mission and compromise, linking academia with social needs.

\section{Conclusion}

During this first year of researching on how the universities are embedding the social innovation in their academic curricula, it seems that several fields of study are relatively adapting methodologies, also facing some obstacles to foster a practical inclusion of it in higher education level. However, those reported courses could have a social dimension, the professors could have a strong social collaboration, but, it does not considere the isolate disciplines as a compulsory, neither optional social innovation or social entrepreneurship course. The Students4Change project proposing a consensus over the social innovation and social entrepreneurship concepts, developing a common understanding about it among the partners, will offer a knowledge contribution with a training course for professors enhancing their competences in order to design and include an innovative methodology on their syllabus. Mentioning some conclusions the importance of HEIs as key element promoting and delivering knowledge-based society (Albulescu \& Albulescu, 2014) leads to attract the government interests at local, regional and national levels. The importance of the development of this strategy - embeding social innovation and social entrepreneurship as formative curricula - demands a clear and concrete methodology, which can lead to social, educational, technological, innovative and economic growth, better enhancing supports attached to quality of life and social problems. Such commitment between universities and society reflect the mutual benefits on those agreements, generating social impact and values. It is necessary to continue researching. A lot of questions have not been addressed in the research field yet. Further research about the social impact of these courses will be the next question addressed on this project.

\section{References}

Abu-Saifan, S. (2012). Social entrepreneurship: definition and boundaries. Technology Innovation Management Review, (February), 22-27.

Albulescu, I., \& Albulescu, M. (2014). The University in the community. The university's contribution to local and regional development by providing educational services for adults. Procedia -Social and Behavioral Sciences, 142, 5-11. https://doi.org/10.1016/j.sbspro.2014.07.578

Bikse, V., Rivza, B., \& Riemere, I. (2015). The Social Entrepreneur as a Promoter of Social Advancement. Procedia - Social and Behavioral Sciences, 185, 469-478. https://doi.org/10.1016/j.sbspro.2015.03.405

Cunha, J., Benneworth, P., \& Oliveira, P. (2015). Social Enrtrepreneurship and Social Innovation: a conceptual distinction. In Handbook of Research on Global Competitive Advantage through Innovation and Entrepreneurship (pp. 616-639). https://doi.org/10.4018/978-1-4666-8348-8 
Domanski, D., Howaldt, J., \& Schroder, A. (2017). Social Innovation in Latin America. Journal of Human Development and Capabilities, 18(2), 307-312. https://doi.org/10.1080/19452829.2017.1299698

Etzkowitz, H. (2008). The Triple Helix: University-Industry-Government Innovation in Action. New York: Routledge. Retrieved from http://ssi.sagepub.com/cgi/doi/10.1177/05390184030423002

Fougère, M., Segercrantz, B., \& Seeck, H. (2017). A critical reading of the European Union's social innovation policy discourse: (Re)legitimizing neoliberalism. Organization, 24(6), 819-843. https://doi.org/10.1177/1350508416685171

Heitor, M. (2015). How university global partnerships may facilitate a new era of international affairs and foster political and economic relations. Technological Forecasting and Social Change, 95, 276-293. https://doi.org/10.1016/j.techfore.2015.01.005

Herrera, A. R., \& Ugarte, H. A. (2008). Claves de la Innovación Social en América Latina y el Caribe. Santiago de Chile.

Martinez, D. A., Gonzalez Alvarez, N., \& Nieto, M. (2015). Emprendimiento social vs Innovación social. Cuadernos Aragoneses de Economía, 24(1-2), 119-140. Retrieved from

http://gide.unileon.es/admin/UploadFolder/emprendimiento_social_vs_innovación_soci al.pdf

Mulgan, G., Tucker, S., Ali, R., \& Sanders, B. (2007). Social Innovation: Why it is, Why it matters and How it can be accelerated. The Young Foundation. London: Basingstoke Press.

Păunescu, C. (2014). Current trends in social innovation research: Social capital, corporate social responsibility, impact measurement. Management and Marketing, 9(2), 103-116. Retrieved from http://www.scopus.com/inward/record.url?eid=2-s2.084907274813\&partnerID=tZOtx3y1

Zahra, S. A., Gedajlovic, E., Neubaum, D. O., \& Shulman, J. M. (2009). A typology of social entrepreneurs: Motives, search processes and ethical challenges. Journal of Business Venturing, 24(5), 519-532. 